\title{
Leaf phenology, growth and photosynthesis in Pseudobombax munguba (Malvaceae)
}

\author{
Ricardo Antonio Marenco ${ }^{1 *} \mathbb{D}$, Francinete de Freitas Sousa ${ }^{2}$, Marcilia Freitas de Oliveira ${ }^{3}$,
}

10.1590/0034-737X201966010001

\begin{abstract}
Munguba (Pseudobombax munguba) is a tree often found in low-land forests of the Amazon region, and there is a paucity of data regarding its ecophysiology. The aim of this work was to determine photosynthetic rates and growth of munguba saplings and to describe leaf phenology of a munguba tree. In greenhouse-grown saplings, diameter growth, leaf expansion, photosynthesis and stomatal conductance were determined. To describe the relationship between photosynthesis and leaf expansion, regression analysis was used. It was also described the leaf phenology of an adult tree by observing foliage changes at one-week intervals for two years. The leaves completed their expansion in 18 days, and leaf greening was completed in 40 days. Photosynthesis positively correlated with leaf expansion, but there was no correlation between stomatal conductance and leaf growth. Growth in diameter was $1.8 \mathrm{~mm}$ month $^{-1}$. Relative growth rate was low, $0.010 \mathrm{~g} \mathrm{~g}^{-1} \mathrm{day}^{-1}$. In the adult tree, leaf shedding was concentrated in July-August and by the second week of September the tree had already produced new leaves. Leaf longevity of munguba is about 11 months. It is hypothesized that leaf phenology of munguba is associated with the increased solar radiation of the dry season.
\end{abstract}

Keywords: Amazon; growth analysis; leaf longevity; net assimilation rate; relative growth rate.

\section{RESUMO}

\section{Crescimento, fotossíntese e fenologia foliar em Pseudobombax munguba (Malvaceae)}

A munguba (Pseudobombax munguba) é uma árvore encontrada com frequência em florestas de baixios da Amazônia e há escassez de informação sobre a sua ecofisiologia. O objetivo deste trabalho foi determinar as taxas fotossintéticas e o crescimento de arvoretas de munguba e descrever a fenologia foliar de uma árvore adulta. Em arvoretas em casa de vegetação, taxas de crescimento em diâmetro, taxas de expansão foliar, fotossíntese e condutância estomática foram determinadas. Para descrever a relação entre a fotossíntese e expansão da folha foi utilizada análise de regressão. Também se descreveu a fenologia foliar de uma árvore adulta ao se observar visualmente as mudanças na folhagem em intervalos de uma semana durante dois anos. As folhas completaram sua expansão em 18 dias e o enverdecimento das folhas foi concluído em 40 dias. A fotossíntese correlacionou positivamente com a expansão foliar, mas não houve correlação entre condutância estomática e crescimento foliar. O crescimento em diâmetro das arvoretas foi de 1,8 $\mathrm{mm}$ mês $\mathrm{s}^{-1}$. A taxa de crescimento relativo foi baixa, $0,010 \mathrm{~g} \mathrm{~g}^{-1} \mathrm{dia}^{-1}$. Na árvore adulta, a queda de folhas concentrou-se em julho-agosto e para a segunda semana de setembro, a árvore já tinha produzido novas folhas. Concluiu-se que a longevidade foliar de munguba é de aproximadamente 11 meses. Hipotetiza-se que a fenologia foliar da munguba esteja associada com a maior radiação solar da estação seca.

Palavras-chave: Amazônia; análise de crescimento; taxa assimilatória líquida; taxa de crescimento relativo; longevidade foliar.

Submitted on March 23rd, 2018 and accepted on December 11 $11^{s d}, 2018$.

${ }^{1}$ Instituto Nacional de Pesquisas da Amazônia (INPA), Coordenação de Dinâmica Ambiental, Manaus, Amazonas, Brazil. rmarenco@inpa.gov

${ }^{2}$ Instituto Nacional de Pesquisas da Amazônia, Coordenação de Capacitação/Programa Institucional de Iniciação Científica, Manaus, Amazonas, Brazil. netefreitas.bio@ gmail.com

${ }^{3}$ Instituto Nacional de Pesquisas da Amazônia, Programa de Pós-graduação em Botânica, Manaus, Amazonas, Brazil. marciliabot@gmail.com

* Corresponding author: rmarenco@inpa.gov 


\section{INTRODUCTION}

In most plants, leaf is the organ that carries out photosynthesis, and hence leaf phenology, the temporal arrangement of leaf emergence and leaf fall, is an important plant trait, as tree growth and the ecosystem functioning depends on carbon fixed by leaves. Leaf phenology is also important because it is related with flowering and fruiting, leaf gas exchange and plant-herbivore interactions (Reich, 1995). The leaves can emerge synchronously (on a single leaf cohort) during the growing season or successively over time, in this case several leaf cohorts can coexist in the same plant (Kikuzawa \& Lechowicz, 2011). It is believed that in the lowland tropics, leaf phenology is mainly determined by variation in precipitation, and consequently by the severity of the dry season, as in these environments there is little variation in temperature over the year (Reich, 1995). In tropical forests and arid environments, a plant that sheds its leaves in the dry season is termed drought deciduous, while a leaf exchanger is a plant that gradually renews all their leaves in less than a year, i.e., it is never bare of leaves during the year (Kikuzawa \& Lechowicz, 2011). Leaf longevity is defined as the elapsed time between leaf emergence and leaf fall, whereas functional leaf longevity (often called leaf life span or realized longevity) describes the amount of time (days) a leaf is capable of performing photosynthesis (Kikuzawa \& Lechowicz, 2011).

Leaf longevity is determined by the genetic make-up of every species and may be influenced by internal and environmental factors. In tropical forests leaf longevity varies across species between one and six years, and it has been suggested that leaves of shade-tolerant saplings can exceed 10 years (Reich et al., 2004; Russo \& Kitajima, 2016). Environmental factors such as light, temperature, mineral nutrition and solar radiation can affect leaf longevity. Thus, it has been found that leaf longevity decreases with increasing light intensity (Harlow et al., 2005; Vincent 2006), but on the contrary intense shading can induce leaf senescence (carbon starvation). Leaf longevity can increase under elevated $\mathrm{CO}_{2}$ concentration (Craine \& Reich, 2001) or in plants grown in low-fertility soils (Shaver, 1981; Russo \& Kitajima, 2016; Reich\& Flores-Moreno, 2017). Leaf senescence may be induced by drought stress or by limited nutrient availability (particularly nitrogen), either to reallocate nutrients to reproductive organs or to reduce water consumption by older leaves (Gan \& Amasino, 1997). For deciduous species leaf longevity can increase with temperature, while the contrary can occur for evergreen species (Kloeke et al., 2011; Kikuzawa et al., 2013). Although ultraviolet radiation UV (280-400 nm, 3 - 5\% of total radiation that reaches the earth surface) can affect leaf senescence (Lim et al., 2007), the UV effect of the most energetic UV radiation (UV-B, 280-315 nm) on leaf physiology still remains to be elucidated (Ballaré \& Austin, 2017).

Senescence is an age-related degradation process occurring at the cellular and tissue level that ultimately leads to death of the senescent organ (Lim et al., 2007). It is influenced by various internal and environmental signals (Kikuzawa \& Lechowicz, 2011). Senescence involves both a decreased expression of genes related to photosynthesis and protein synthesis and an increased expression of genes associated with senescence (Lim et al., 2007). Water stress can induce leaf senescence because an increased production of reactive oxygen species can trigger the expression of genes involved in protein degradation and remobilization of nutrients during stress (Munné-Bosch \& Alegre 2004; Lee et al., 2012).

Munguba (Pseudobombax munguba (Mart. \& Zucc.) Dugand., Malvaceae) is a deciduous and fast growing tree that can reach $26 \mathrm{~m}$ in height and $60 \mathrm{~cm}$ in diameter (Lorenzi, 2009). It occurs in the Amazon region, in floodplain forests and river banks. The tree has about eight leaflets per leaf. The blooming (anthesis) of munguba can occur in April-May and fruit maturity in September-October; the seed is small $(238 \mathrm{mg})$ and its germination takes about 1020 days (Lorenzi, 2009). The bole of munguba has been used for making canoes, floats and frames. Strong fibers can be extracted from the tree (after macerating the bark for 2-3 weeks under water), which have been used for making ropes (Fonseca, 1922), whereas the seed floss can be used as stuffing material (Lorenzi, 2009). Because of its nearly cylindrical bole and the characteristics of its flowers, the munguba can also be used as an ornamental tree (Fern, 2014). The aims of this work were to evaluate the biomass gain in one-year old saplings and the relationship between leaf allometry and photosynthesis. A second objective was to describe the leaf phenology of an adult munguba tree.

\section{MATERIALS AND METHODS}

The study was carried out at Campus III (V-8) of the National Institute for Research in the Amazon (INPA Instituto Nacional de Pesquisas da Amazônia) in ManausAM. In Manaus city, mean values of climatic data (1961 1990) are as follows (INMET, http://www.inmet.gov.br): Total insolation is about $5.0 \mathrm{~h}$ per day (range of $3.92 \mathrm{~h} \mathrm{day}^{-1}$ wet season to 6.51 hours per day in the dry season); mean relative humidity, $83 \%$; mean temperature, $26.7^{\circ} \mathrm{C}$, and mean evaporation (Piché) is $65 \mathrm{~mm}$ per month (Table 1). The study involved two experiments. Experiment 1 lasted 127 days and was conducted under greenhouse conditions, whereas in a second experiment, the phenology of an adult tree was monitored for two years. 
Experiment 1: In this experiment, 15 plants of Pseudobombax munguba (Malvaceae) were produced from seeds (collected from a mother tree located at Campus III, INPA). The experiment was initiated on August 18, 2015 (Julian day 230), when the saplings were 340-days old, and ended on December 23, 2015 (day 357). At the beginning of the experiment the saplings were $67.7 \pm 8.3$ $\mathrm{cm}$ in height, $9.06 \pm 1.57 \mathrm{~mm}$ in stem diameter (at $6 \mathrm{~cm}$ from the base of the plant) and had 5.6 leaves per plant and a leaf area of $1350 \mathrm{~cm}^{2}$ per plant. During the experimental period (127 days) the plants were kept in a greenhouse. In the greenhouse mean irradiance (over a $12-\mathrm{h}$ period) was about $200 \mu \mathrm{mol} \mathrm{m}{ }^{-2} \mathrm{~s}^{-1}$, mean temperature $27.5^{\circ} \mathrm{C}$ and $\mathrm{RH}$ $70-80 \%$. The saplings were grown in pots containing 7 $\mathrm{kg}$ of clay-sandy soil fertilized (5.0 g per pot) with NPK fertilizer $\left(10 \% \mathrm{~N}, 10 \% \mathrm{P}_{2} \mathrm{O}_{5}\right.$ and $\left.10 \% \mathrm{~K}_{2} \mathrm{O}\right)$.

During the experiment, plant height $(H)$ and diameter $(D)$ were measured at one-week intervals. The height (from the base of the plant to stem tip) was measured with a tape and the stem diameter (at $6 \mathrm{~cm}$ above the soil surface) was measured with digital calipers. To estimate the leaf area per plant at the beginning and at the end of the experimental period, in four additional plants (total of 28 leaves) the central leaflet was measured (width and length) and the leaf area of the whole leaf (including the central leaflet) determined using a leaf area meter (Li-3000, Li-Cor, Lincoln, USA). Total biomass accumulation (g per plant, including leaves, stem and roots) was calculated using Equation 1, which was generated for andiroba saplings (Carapa surinamensis) by Oliveira \& Marenco (2019):

$$
B(g)=10.157[\exp (0.1692 D)]
$$

Where $D$ represents the stem diameter (in millimeter). Relative growth rate (RGR) and net assimilation rate (NAR) were calculated as follows (Hunt et al., 2002):

$$
\begin{aligned}
& R G R\left(\mathrm{~g} \mathrm{~g}^{-1} \mathrm{day}^{-1}\right)=\frac{\ln W_{2}-\ln W_{1}}{\mathrm{t}_{2}-\mathrm{t}_{1}} \\
& N A R\left(\mathrm{~g} \mathrm{~m}^{-2} \text { day }^{-1}\right)=\frac{W_{2}-W_{1}}{t_{2}-t_{1}} \times \frac{\ln A_{2}-\ln A_{1}}{A_{2}-A_{1}}
\end{aligned}
$$

Where $W_{2}$ and $W_{1}$ represent the biomass of the plant (in gram, at $t_{2}$ and $t_{1}$, respectively), $A_{2}$ and $A_{1}$ the leaf area of the whole plant (in square meter, at $t_{2}$ and $t_{1}$, respectively), In indicates natural logarithm, and $\left(\mathrm{t}_{2}-\mathrm{t}_{1}\right)$ denotes the interval between the beginning $\left(t_{1}\right)$ and end $\left(t_{2}\right)$ of the experiment, i.e. $\left(\mathrm{t}_{2}-\mathrm{t}_{1}\right)=127$ days.

In order to determine the variation of leaflet size with time, three leaves were labeled on each plant (15 plants in total), which were monitored for a period of 71 days. In these leaves, we measured (accuracy of $1 \mathrm{~mm}$ ) central leaflet length and the central leaflet width. These measurements were initiated when the central leaflet was about $1-\mathrm{cm}$ wide. Then it was also measured the relative chlorophyll content (hereinafter referred to as the SPAD value) using a portable chlorophyll meter (SPAD-502, Minolta Camera Co., Osaka, Japan).

When the saplings reached 427 days of age (November $13,2015)$ we measured light saturated photosynthesis $\left(P_{\text {Nsat }}\right)$ and stomatal conductance $\left(g_{\mathrm{s}}\right)$ in the central leaflet of four leaves per plant. $P_{\mathrm{Nsat}}$ and $g_{\mathrm{s}}$ were measured in five plants, which were randomly selected from the group of 15 plants. The leaves were selected in such a way as to represent leaf age variation. That is, from new leaves, with at least $2.8-\mathrm{cm}$ wide (to fully cover the IRGA's leaf chamber), to fully developed leaves. This leaf size corresponded to new leaves ranging in age from 10 to 40 days. $P_{\text {Nsat }}$ and $g_{\mathrm{s}}$ were measured using a portable infrared gas analyzer, IRGA(Li-6400XT, Li-Cor, Lincoln, NE, USA). Measurements were carried out between 08:00 and 14:00. In the leaf chamber, leaf temperature was $27 \pm 1^{\circ} \mathrm{C}$, air

Table 1: Mean values of total solar radiation $\left(S_{\mathrm{Rad}}\right)$, photosynthetically active radiation (PAR), temperature (maximum, $T_{\max }$; minimum, $T_{\min }$ and mean $T_{\text {mean }}$ ), relative humidity (RH), evaporation (Piché evaporamiter, inside a meteorological shelter) and rainfall in Manaus from 1961 to 1990 (data compiled from INMET, http://www.inmet.gov.br). The dry season includes the months from June to October, whereas the wet season includes months from November to May (October is often considered a transition month, but it was included in the dry season). Total solar radiation $\left(S_{\mathrm{Rad}}\right)$ was calculated using insolation data $\left[S_{\mathrm{Rad}}\left(\mathrm{MJ} \mathrm{m}^{-2} \mathrm{day}^{-1}\right)=8.767+\right.$

\begin{tabular}{|c|c|c|}
\hline Climatic parameter & Dry season & Wet season \\
\hline$T_{\max }\left({ }^{\circ} \mathrm{C}\right)$ & $32.1 \pm 0.90$ & $30.9 \pm 0.61$ \\
\hline$T_{\text {mean }}\left({ }^{\circ} \mathrm{C}\right)$ & $27.1 \pm 0.634$ & $26.3 \pm 0.45$ \\
\hline$T_{\min }\left({ }^{\circ} \mathrm{C}\right)$ & $23.2 \pm 0.41$ & $23.3 \pm 0.22$ \\
\hline RH (mean, \%) & $79.2 \pm 2.49$ & $85.9 \pm 2.34$ \\
\hline Rainfall (mm month ${ }^{-1}$ ) & $86.9 \pm 28.4$ & $267.6 \pm 55.1$ \\
\hline Insolation (hour day ${ }^{-1}$ ) & $6.51 \pm 0.68$ & $3.92 \pm 0.67$ \\
\hline Solar radiation $\left(\mathrm{MJ} \mathrm{m}^{-2}\right.$ day $\left.^{-1}\right)$ & $17.86 \pm 0.95$ & $14.24 \pm 0.94$ \\
\hline $\operatorname{PAR}\left(\mathrm{mol} \mathrm{m}^{-2}\right.$ day $\left.^{-1}\right)$ & $37.0 \pm 1.96$ & $29.5 \pm 1.95$ \\
\hline Evaporation (Piché, mm month ${ }^{-1}$ ) & $82.3 \pm 13.21$ & $52.8 \pm 8.54$ \\
\hline
\end{tabular}
$1.397 h, r^{2}=0.91, n=341$ days, whereas $h$ is daily insolation (hour day ${ }^{-1}$ )]; whereas PAR was calculated multiplying total solar radiation by 0.45 (PAR fraction in total radiation) and considering that $1 \mathrm{~mol}$ PAR $=217 \mathrm{~kJ}$ (energy). 
humidity $70 \%, \mathrm{CO}_{2} 400 \mathrm{ppm}$, and PAR $1000 \mu \mathrm{mol} \mathrm{m}^{-2} \mathrm{~s}^{-1}$. Before gas exchange measurements, length, width and the SPAD value of the central leaflet were also measured in order to relate these parameters with photosynthesis data. The relationship between leaflet size (length and width) and SPAD values and between leaflet size and photosynthesis data was examined by regression analysis. The data were analyzed using $\operatorname{Excel}^{(\mathrm{R})} 2010$.

Experiment 2: In the second experiment, leaf phenology was monitored by observing foliage changes of one adult tree (the mother tree used to collect seeds) at one-week intervals for two years (from August 2015 to September 2017). The mother tree (located at $03^{\circ} 05^{\prime} 29^{\prime \prime} \mathrm{S}, 59^{\circ} 59^{\prime} 35^{\prime \prime} \mathrm{W}$ ) was $50 \mathrm{~cm}$ in diameter (density wood of $0.244 \mathrm{~g} \mathrm{~cm}^{-3}$ ) and about $25 \mathrm{~m}$ in height, in September 2017. Photographs were taken to illustrate leaf phenology.

\section{RESULTS}

Experiment 1: The saplings grew $59 \mathrm{~cm}$ in height $(67$ $126 \mathrm{~cm})$ and $8 \mathrm{~mm}$ in diameter $(9-17 \mathrm{~mm})$ during the 127 days of the experimental period (Figure 1). On average, the height and diameter growth rates were $5.0 \mathrm{~mm}^{-1 a y}{ }^{-1}$ and $0.063 \mathrm{~mm} \mathrm{day}^{-1}$ (Figure 1A). Mean biomass gain per plant was $2.94 \mathrm{~g}$ day $^{-1}$ during the experimental period (47.0 to $178.3 \mathrm{~g}$ per plant) which led to a mean RGR of $0.0105 \mathrm{~g} \mathrm{~g}^{-1} \mathrm{day}^{-1}$ (Figure 1B). Correlation between the central leaflet length $(\mathrm{x}, \mathrm{cm})$ and leaf area $\left(\mathrm{y}, \mathrm{cm}^{2}\right)$ was described by the equation, $\mathrm{y}\left(\mathrm{cm}^{2}\right)=-214.5+24.42 \mathrm{x}(p=$ $<0.001, r^{2}=0.91$, Figure 2 ), and on average, leaf area increased from $1353 \mathrm{~cm}^{2}$ per plant beginning of the experiment (day 230) to $4519 \mathrm{~cm}^{2}$ per plant (day 357) at the end of the experimental period (Figure 2). This led to an increase of $3166 \mathrm{~cm}^{2}$ per plant (i.e. $24.93 \mathrm{~cm}^{2}$ per day). The increase in biomass and leaf area, led to a net assimilation rate (NAR) of $3.94 \mathrm{~g} \mathrm{~m}^{-2}$ day $^{-1}$, during the evaluation period (Figure 1B). In the greenhouse the leaves reached maximum leaf expansion in about 18 days, when they reached $4.66 \pm$ $0.94 \mathrm{~cm}$ in width and $16.45 \pm 3.26 \mathrm{~cm}$ in length (Figure 3). One can see in this Figure (square symbols) that SPAD values increased rapidly in the first 40 days until reaching maximum values (SPAD of $\approx 40$ units) in leaves 45 - 50 days old.

There was a positive correlation between $P_{\text {Nmax }}$ and leaflet length and leaflet width ( $p<0.01$, Figure 4A), and in fully developed leaves the higher photosynthesis rates were $8-10 \mu \mathrm{mol} \mathrm{m}^{-2} \mathrm{~s}^{-1}$. On the other hand, the $g_{\mathrm{s}}$ values showed no correlation with changes in leaflet length and leaflet width (Figure 4B). There was a positive relationship between leaflet length and leaflet width and the relative chlorophyll content - the SPAD values $(p<0.01$, Figure $4 \mathrm{C}$ ), but there was no correlation between $g_{\mathrm{s}}$ and the SPAD values (Figure 4D).

Experiment 2: In 2015, leaf senescence started in the firstsecond week of July, and then the tree also began to bloom (Table 2). Leaf fall was concentrated in July-August (Table 2), and the Julian day 233 (August 21, 2015 -leaf emergence, Figure 5A) was considered the starting time for calculating leaf longevity. By September 09, 2015 (Julian day 252) most of the leaves were fully developed, and they were about 20 days old (Figure 5B). One year later,

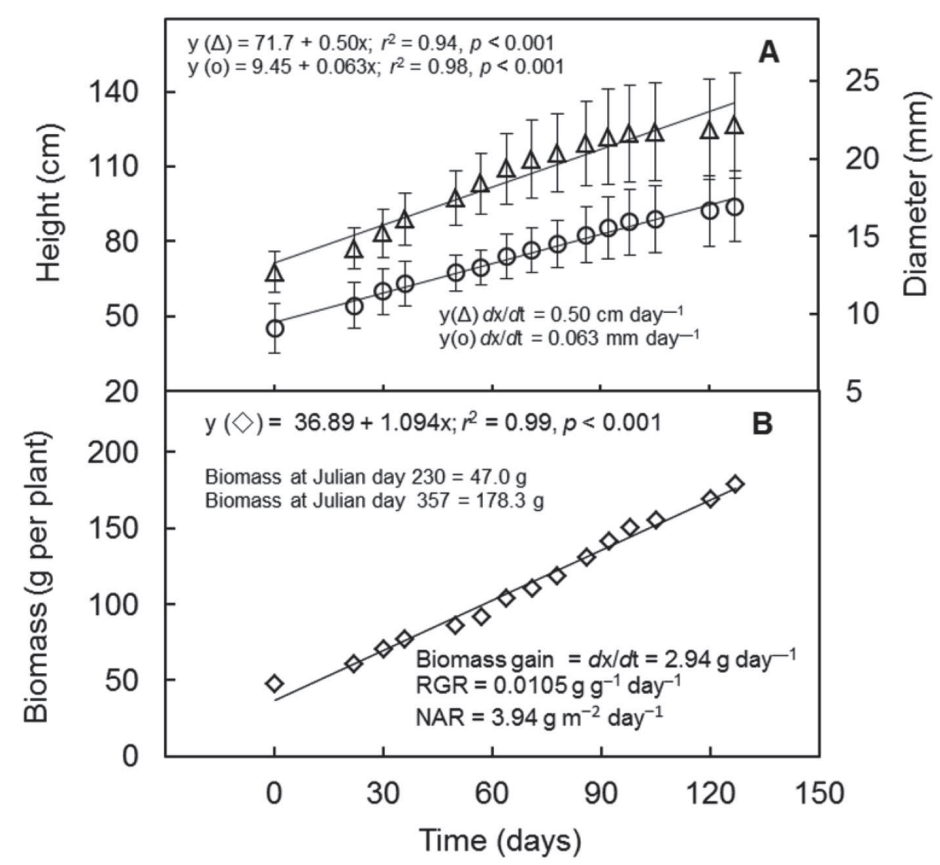

Figure 1: Growth in height $(\Delta$, triangle) and stem diameter (o, circle, A) and biomass accumulation per plant (B) during the experimental period in munguba saplings. The vertical line on each symbol (panel A) denotes the standard deviation. 
leaf senescence began again, as it is shown in Figure 5C, when the leaves were about 300 days old (Table 2). It was estimated that at least $50 \%$ of the leaves had fallen by July 19 (2016) and those still on the tree were in the final senescence stage. Therefore, July 19 (Julian day 201, Figure 5D) was considered to be the end of annual leaf life cycle, as the leaves still in the tree were very senescent. Thus, it was inferred that leaf longevity of this tree was about 330 days (i.e. $365-233+201=333$ days, $\approx 330$ ).

By August 16, 2016, the tree had shed all its leaves (Figure 5 E), and by September 08, 2016 the tree had new leaves, about 10-20 days old (Figure 5F). In Figure 5G, one can see that the tree was bare on August 22, 2017 and with new leaves on September 15, 2017 (Figure 5H). During the study period, flowering and fruit development occurred between July and August (Figure 5D-E). The

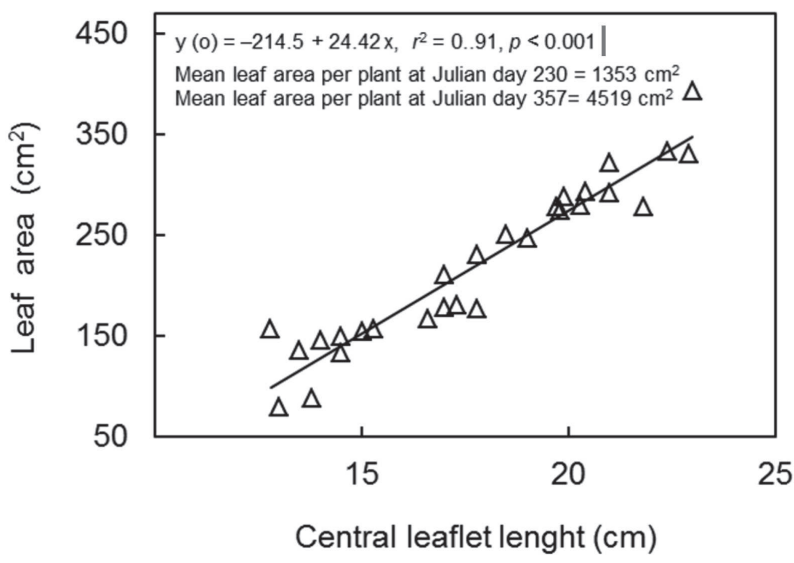

Figure 2: Relationship between leaf area and the central leaflet length ( $n=28$ leaves from four plants). This equation was used to estimate total leaf area per plant. Estimated mean leaf area per plant was $1353 \mathrm{~cm}^{2}$ on August 18, 2015 and $4519 \mathrm{~cm}^{2}$ on December 23, 2015; i.e., the beginning and end of the experimental period, respectively.

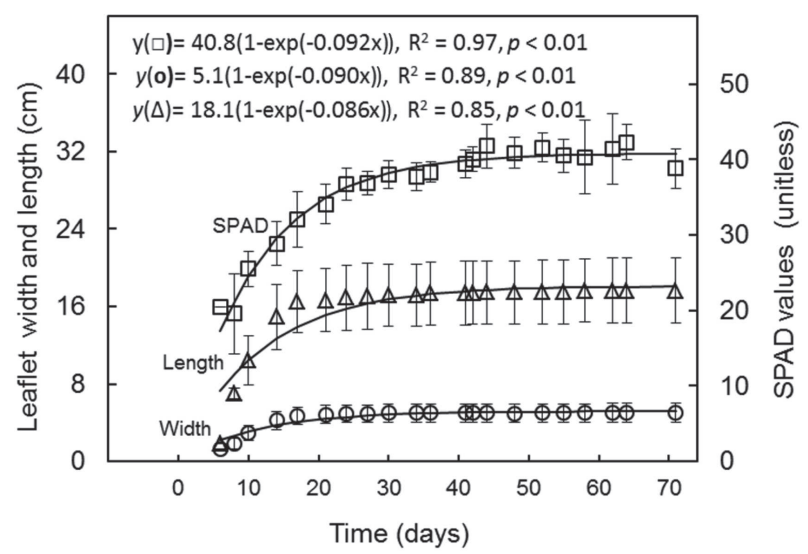

Figure 3: SPAD values ( $\square$ : square), central leaflet width (o, circle), and central leaflet length ( $\Delta$ : triangle) as a function of time from leaf emergence (in days) in munguba saplings grown under greenhouse conditions. The vertical line on each symbol denotes the standard deviation. period of leaf shedding was about four weeks, mainly concentrated in the last week of July and the first three weeks of August, and thus, the tree was bare or almost bare during that same period. The tree produced oblong, red-orange fruits, about $10 \mathrm{~cm}$ in diameter and $13 \mathrm{~cm}$ in length, the leaves had 6 - 8 leaflets, and the central leaflet was about 6 - $8 \mathrm{~cm}$ wide and 18 - $22 \mathrm{~cm}$ long (Table 2).

\section{DISCUSSION}

Munguba tree grew about $1.9 \mathrm{~mm}$ per month in diameter and $15 \mathrm{~cm} \mathrm{month}^{-1}$ in height, which is higher than growth rates (in diameter) observed in andiroba (Carapa spp) under greenhouse conditions, $0.9 \mathrm{~mm}^{\text {month }}{ }^{-1}$ (Oliveira \& Marenco, 2019). However, this growth rates is similar to that reported by Camargo \& Marenco (2012) in andiroba in the open, 1.9 - $2.0 \mathrm{~mm} \mathrm{month}^{-1}$ (in diameter). The RGR found in munguba $\left(0.0105 \mathrm{~g} \mathrm{~g}^{-1} \mathrm{day}^{-1}\right)$ is lower than the RGR (0.04 - $0.041 \mathrm{~g} \mathrm{~g}^{-1}$ day $^{-1}$ ) reported by Shipley (2006) and Antúnez et al. (2001) for other woody plants. However, the NAR value found in munguba $\left(3.94 \mathrm{~g} \mathrm{~m}^{-2}\right.$ day $\left.{ }^{-1}\right)$ is similar to the mean values of $3.6-3.7 \mathrm{~g} \mathrm{~m}^{-2} \mathrm{day}^{-1}$ reported by Shipley (2006) and Antúnez et al. (2001). Since RGR is the product of NAR and leaf area ratio (LAR, total leaf area divided by total plant biomass), one can conclude that the low RGR found in munguba is the result of a low LAR. To further explore this hypothesis we harvested four munguba saplings (mean of $11.4 \mathrm{~cm}$ diameter, $89.4 \mathrm{~cm}$ height, and $0.1658 \mathrm{~m}^{2}$ of leaf area) and calculated LAR, specific leaf area (SLA, leaf area to leaf mass ratio) and leaf mass ratio (LMR, whole plant leaf biomass divided by total biomass). LAR is the product of LMR and SLA. It was found that the fraction of the total biomass $(97.07 \mathrm{~g})$ allocated to plant organs was as follows: roots, $33.29 \mathrm{~g}$; stems, 58.82 $\mathrm{g}$, and only $5.04 \mathrm{~g} \mathrm{(5.2 \% )} \mathrm{of} \mathrm{the} \mathrm{total} \mathrm{biomass} \mathrm{was} \mathrm{allocated}$ to leaves, which led to a LAR of $1.71 \mathrm{~m}^{2} \mathrm{~kg}^{-1}$ ). This is very low, as in many woody species LAR is about $12.3 \mathrm{~m}^{2} \mathrm{~kg}^{-}$ ${ }^{1}$ (Antúnez et al., 2001). Although SLA was uncommonly high $\left(33.2 \mathrm{~m}^{2} \mathrm{~kg}^{-1}\right.$, i.e. the leaves were very thin), that high SLA value was not enough to compensate for the sharp decline in LMR, that was only 0.052 (5.04/97.07). The LMR value found in munguba was almost eight times lower than the mean value ( 0.43 over several woody species) reported by Antúnez et al. (2001). It is apparent that the amount of biomass allocated to leaf biomass in munguba was very low, whereas the proportion of biomass allocated to stem was high $(60.6 \%)$. The SLA of munguba under greenhouse was still higher than that $\left(24.5 \mathrm{~m}^{2} \mathrm{~kg}^{-1}\right)$ found in Goupia glabra (a light demanding tree) growing under the forest understory (Marenco \& Vieira, 2005). This suggests that the light intensity in the greenhouse was low for munguba, and this stimulates a greater biomass allocation to stem, in detriment of biomass allocation to 


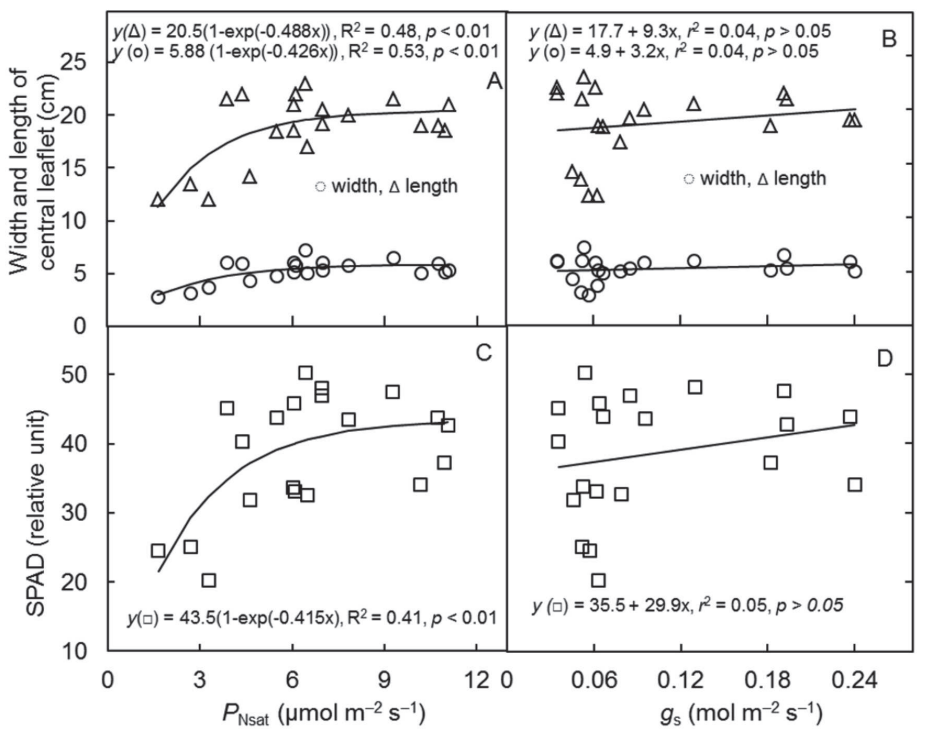

Figure 4: Relationship between width (o, empty circle), length ( $\Delta$, triangle) of the central leaflet and light saturated photosynthesis $\left(P_{\text {Nat }}\right)(\mathrm{A})$ and between central leaflet width and leaflet length and stomatal conductance, $g_{\mathrm{s}}(\mathrm{B})$. Panels $\mathrm{C}$ and D show the relationship between the central leaflet and $P_{\text {Nsat }}$ and $g_{\mathrm{s}}$ and SPAD values. Data from 427-day-old munguba saplings.

Table 2: Leaf phenology changes over time in an adult munguba tree (50 cm in diameter, $25 \mathrm{~m}$ in height, in September 2017) located at $03^{\circ} 05^{\prime} 29^{\prime \prime} \mathrm{S}, 59^{\circ} 59^{\prime} 35^{\prime \prime} \mathrm{W}$ ).

\begin{tabular}{lll}
\hline Date & Phenology of the tree & Panels in Figure 5 for illustration \\
\hline July $07-14,2015$ & $\begin{array}{l}\text { Leaf senescence started and the tree began to bloom. } \\
\text { Leaf fall was observed. }\end{array}$
\end{tabular}

August 03, 2015 The tree showed senescent leaves and intense leaf fall was observed. The tree had flowers and fruits.

intense leaf fall in the first two weeks of August), some fruits had reached their final size. Some new leaves began to emerge on 17-21 August, 2015.

August 25, 2015

The tree had fruits and new leaves had emerged all over the tree.
See Figure 5A. August 21 (day 233) was considered the starting time for leaf emergence. About one month after leaf senescence began.

See Figure 5B.The leaf had 6-8 leaflets. In a fully developed leaf, the central leaflet was about 18 $22 \mathrm{~cm}$ in length and $6-8 \mathrm{~cm}$ in width.

September 09, 2015

New leaves were at the final stage of development. Leaf age was about 20 days old.

June 16, 2016 One year later, leaf senescence began again.

Most of the leaves still on the tree were in the final

July 09-19, 2016 senescence stages. The tree had fruits. By July 19 (day 201) at least $50 \%$ of the leaves had fallen.
See Panel 5C (day 168). The leaves were about 300 days old.

See Figure 5D. On July 19, 2016 the leaves were about 330 days old. This was assumed as the end of leaf life span, as the leaves still in the tree were completely senescent.

See panel 5E. The flowers were white-cream and about $10 \mathrm{~cm}$ in diameter, whereas the fruits were oblong, about $10 \mathrm{~cm}$ in diameter and $13 \mathrm{~cm}$ in length.

August 16-19, 2016

The tree was entirely bare, all leaves had fall. The tree had fully developed fruits.

Figure 5F.

September 08, 2016

Two years later from the beginning, on The tree had new leaves, about 10-20 days old.

August 22 and

The tree was bare again in August and with new leaves in September.

See Figure 5G,H.

September 15, 2017

Rev. Ceres, Viçosa, v. 66, n.1, p. 001-010, jan/fev, 2019 
leaves. This shows that munguba could be better adapted to sunny environments, as suggested by Lorenzi (2009), who describes this species as heliophyte and pioneer.

$P_{\text {Nsat }}$ values recorded in fully expanded leaves are within the range of values found in saplings of other Amazonian trees, such as Carapa guianensis, $8.97 \mu \mathrm{mol}$ $\mathrm{m}^{-2} \mathrm{~s}^{-1}$ (Camargo \& Marenco, 2012) and Garcinia brasiliensis, $7.53 \mu \mathrm{mol} \mathrm{m}^{-2} \mathrm{~s}^{-1}$ (Gouvêa \& Marenco, 2018). Although the $P_{\text {Nsat }}$ values are within the expected rates for tree species, this assimilation rates did not lead to high RGR, which suggests the actual photosynthetic rate in the greenhouse was well below the values recorded under light saturated conditions. Also, at the plant level, total carbon assimilation (and hence RGR) depends also on the amount of carbon allocated to leaves, which was low in munguba saplings. Photosynthetic rates increased with leaf expansion (Figure 4), which shows that photosynthesis increases during leaf development (Tichá et al., 1985). SPAD values increased steadily up to about 40 days (Figure 4), but leaf expansion stop increasing at about 18 days, which indicates that leaf greening continued for a few days after the leaf had reached its full expansion. Relative chlorophyll content (SPAD values) had a positive correlation with the photosynthetic rates (Figure 4), which is not unexpected as carbon assimilation depends on the amount of energy captured by chlorophylls.

The munguba tree shed its leaves in July August (in the middle of the dry season) and it was considered that the leaf cycle ended when at least $50 \%$ of leaf had fallen (Matsuki \& Koike, 2006). Thus, it is feasible to assume that leaf longevity of this tree was 330 days (from August

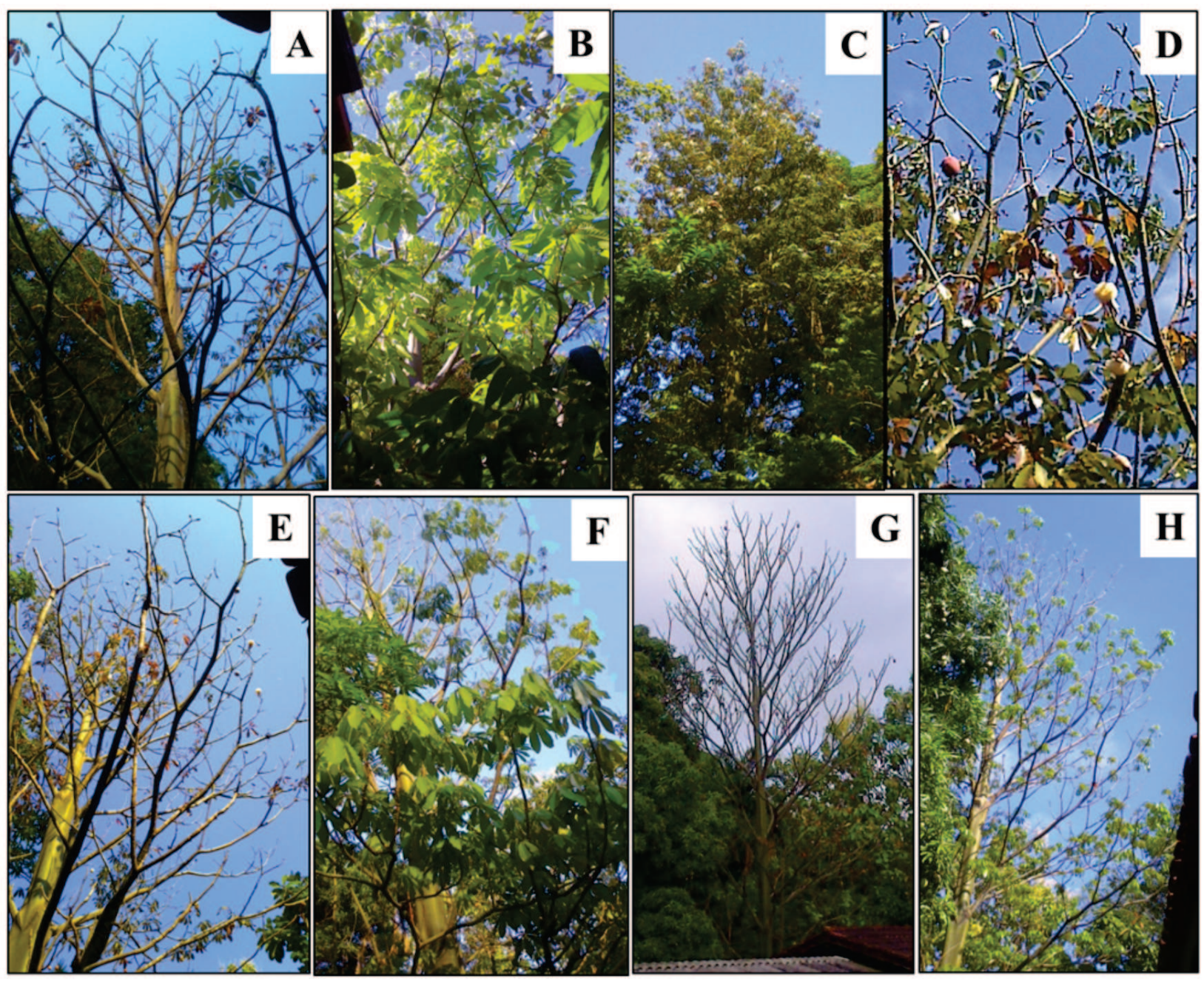

Figure 5: Changes in leaf phenology in the adult tree (mother tree) of munguba. (A) Munguba tree on August 21, 2015 (starting time for leaf emergence). (B), the tree with well-developed new leaves on September 9, 2015. One year later: (C) the tree was with senescent leaves on June 16, 2016; (D) on July 19, 2016, at least 50\% of leaves had fallen, and the remaining leaves were very senescent; the tree had well-developed fruits; (E) on August 16, 2016, the tree was bare again and it had flowers and fruits; (F) the tree had new leaves (10-20 days old) on September 08, 2016;(G) the tree was bare again on August 22, 2017, and in panel H (September 15,2017 ) the tree was again with new leaves. In panels $\mathrm{G}$ and $\mathrm{H}$ there is a neighboring tree on the left-hand side of the tree (photos R.A. Marenco). 
21, 2015 to July 19, 2016). If we considered that the contribution of senescent leaves to photosynthesis is very low (Gan \& Amasino, 1997), it is plausible to conclude that the functional leaf longevity of the munguba tree can be reduced to 300-315 days.

The pattern of leaf shedding and leaf emergence found in this study was more concentrated than that reported by Schöngart et al. (2002) who found that in a floodplain forest of central Amazonia, munguba trees dropped their leaves between March and July and produced new leaves in September January. This discrepancy can be ascribed to the fact that in this study the munguba tree was not subjected to flooding stress.

It has been postulated that across species the annual pattern of leaf shedding in rainforest is rather flat, i.e. each month sharing about 5 - $13 \%$ of total annual leaf drop (Reich, 1995). In seasonal tropical environments, as dryness increases (i.e. precipitation declines and vapor pressure deficit increases) a greater proportion of species becomes deciduous, with leaf longevity roughly following the length of the wet season (Reich, 1995). Although in central Amazonia the dry season is rather short, in most species leaf renewal seems to increase in the dry season (Lopes, 2015). It is still unknown which environmental clue triggers leaf shedding of deciduous trees (such as munguba) in central Amazonia. In rainforests located close to the Equator $\left(5^{\circ} \mathrm{N}\right.$ to $\left.5^{\circ} \mathrm{S}\right)$, maximum variation of day-length is of $35 \mathrm{~min}$ and the mean temperature variation is small, from $26.3{ }^{\circ} \mathrm{C}$ (wet season) to $27.1^{\circ} \mathrm{C}$ in the dry season (Table 1 ). Thus, one can assume that the contribution of photoperiod and temperature to leaf phenology is small. Mendes \& Marenco (2010) found a small difference in leaf area index (LAI) between the dry season and the wet season, 4.7 versus 5.1. Dias \& Marenco (2016), however, did not find an effect of the dry season on tree growth in 120 trees (28 species) in central Amazon, perhaps because the correlation between LAI and above-ground net primary production is low $\left(r^{2}=0.33\right.$; Asner et al., 2003). Morton et al. (2014) found that the greening (a proxy of photosynthetic rates) of the Amazon forest tends to remain stable over the year, which suggests that tree growth and photosynthetic rates are not limited by water stress.

We argue that in the munguba tree (this study) leaf shedding and the environmental clue that triggers the emergence of new leaves are not a direct response to drought stress. For example, the dry season of 2015 (six months below $100 \mathrm{~mm} \mathrm{month}^{-1}$ ) was more prolonged than that of 2017, only two months below $100 \mathrm{~mm} \mathrm{month}^{-1}$ (INMET, http://www.inmet.gov.br). However, that variation in drought length apparently did not have a discernible effect on the phenological pattern of munguba (Figure 5).
As photoperiod, temperature and water stress appear to have little effect on triggering leaf shedding in this munguba tree, we hypothesized that leaf shedding of this tree can be related to the increase in insolation (and thereby in direct solar radiation), which is higher in the dry season, $3.92 \mathrm{~h} \mathrm{day}^{-1}$ (wet season) versus $6.51 \mathrm{~h}$ day ${ }^{1}$ in the dry season (Table 1 ). If leaf shedding in munguba is induced by a critical daily insolation (or by accumulated insolation over time), then the tree will begin to shed leaves once that threshold is reached. This could explain the lack of a discernible effect of dry season length on the leaf phenology between the years 2015 and 2017. Of course, some indirect effects of drought can be associated with leaf phenology. In the dry season maximum temperatures increase. This can lead to high VPD, particularly at midday. This is important, because the typical response of an increase in VPD is a decline in photosynthetic rates (Maruyama et al., 2005), because high VPD induces stomatal closing. The drop in photosynthesis and the increase of irradiance can ultimately lead to an increase in the amount of reactive oxygen species (ROS). Besides its role in signaling, ROS are very toxic molecules capable of causing irreversible damage to chloroplasts. It has been shown that degradation of proteins and ROS accumulation occur in senescing leaves (Nakamura \& Izumi, 2018). In this work we show that leaf senescence and fruiting occurred synchronically, which makes sense as factors such as self-shading and fruiting also play a role in leaf senescence (Kikuzawa \& Lechowicz, 2011). The elapsed time between leaf fall and leaf emergence was short (about four weeks), which seems to be uncorrelated with the length of the dry season.

One needs to be cautious in extrapolating data from one tree to the ecosystem. This tree, however, can give us a clue of the performance of the trees in the ecosystem. Although leaf shedding tends to increase in the dry season, it does not occur synchronously across all species. Thus, light can penetrate deeper in the canopy of a neighboring tree when its companion tree is exchanging leaves at increased rates. It follows that at the ecosystem level photosynthesis tends to remain rather constant over time, as suggested by Morton et al. (2014). This can explain the rather constant monthly growth rates of trees often observed in central Amazonia, particularly under the rainfall patterns of a typical year, when the dry season is not too prolonged (Dias \& Marenco, 2016).

\section{CONCLUSIONS}

In the greenhouse it was found that the leaves expanded rapidly and fully expanded leaves have photosynthetic rates similar to those found in saplings of other species. Munguba saplings show fast growth rates $\left(15 \mathrm{~cm} \mathrm{month}^{-1}\right.$ in height and about $1.9 \mathrm{~mm} \mathrm{month}^{-1}$ in 
diameter). This suggests that munguba can be tested in reforestation programs particularly in areas with a mild drought period. It was observed a low RGR in munguba saplings perhaps because the light intensity in greenhouse was rather low. Leaf shedding of munguba occurred during the dry season, and it was concentrated in July August. There was a lag of about one month between beginning of the leaf fall period and the emergence of new leaves. We hypothesized that leaf phenology of munguba is associated with the greater insolation and increased solar radiation of the dry season.

\section{ACKNOWLEDGMENTS}

To the MCTI-INPA and Conselho Nacional de Desenvolvimento Científico e Tecnológico $(\mathrm{CNPq})$ for scholarship to MFO and FFS, and fellowship to RAM. To the anonymous reviewers for their useful comments and suggestions that greatly improved the quality of the manuscript.

\section{REFERENCES}

Antúnez I, Retamosa EC \& Villar R (2001) Relative growth rate in phylogenetically related deciduous and evergreen woody species. Oecologia, 128:172-180.

Asner GP, Scurlock JMO \& Hicke JA (2003) Global synthesis of leaf area index observations: implications for ecological and remote sensing studies. Global Ecology and Biogeography, 12:191-205.

Ballaré CL \& Austin AT (2017) UV Radiation and Terrestrial Ecosystems: Emerging Perspectives. In: Jordan BR (Ed.) UV-B Radiation and Plant Life: Molecular Biology to Ecology. Oxfordshire, CABI International. p.23-38.

Camargo MAB \& Marenco RA (2012) Growth, leaf and stomatal traits of crabwood (Carapa guianensisAubl.) in central Amazonia. Revista Árvore, 36:07-16.

Craine JM \& Reich PB (2001) Elevated $\mathrm{CO}_{2}$ and nitrogen supply alter leaf longevity of grassland species. New Phytologist, 150:397-403.

Dias DP \& Marenco RA (2016) Tree growth, wood and bark water content of 28 Amazonian tree species in response to variations in rainfall and wood density. iForest-Biogeosciences and Forestry, 09:445-451

Fern K (2014) Useful Tropical Plants Database: Pseudobombax munguba. Available at: http://tropical.theferns.info/viewtropical.php? id=Pseudobombax + munguba. Access on: November 26, 2018

Fonseca ET (1922) Indicador de madeiras e plantas úteis do Brasil. Rio de Janeiro, Oficinas Gráficas Villas Boas. Available at: http:/ /www.biodiversitylibrary.org. Access on: November 30, 2018.

Gan S \& Amasino RM (1997) Making sense of senescence (molecular genetic regulation and manipulation of leaf senescence). Plant Physiology, 113:313-319.

Gouvêa PRS \& Marenco RA (2018) Is a reduction in stomatal conductance the main strategy of Garcinia brasiliensis (Clusiaceae) to deal with water stress?. Theoretical and Experimental Plant Physiology, 30:321-333.

Harlow BA, Duursma RA \& Marshall JD (2005) Leaf longevity of western red cedar (Thuja plicata) increases with depth in the canopy. Tree Physiology, 25:557-562.
Hunt R, Causton DR, Shipley B \& Askew AP (2002) A modern tool for classical plant growth analysis. Annals of Botany, 90:485-488

Kikuzawa K \& Lechowicz MJ (2011) Ecology of Leaf Longevity. New York, Springer. 147 p.

Kikuzawa K, Onoda Y, Write IJ \& Reich PB (2013) Mechanisms underlying global temperature-related patters in leaf longevity. Global Ecology and Biogeography, 22:982-993.

Kloeke AEEO, Douma JC, Ordonez JC, Reich PB \& van Bodegom PM (2011) Global qualification of contrasting leaf life span strategies for deciduous and evergreen species in response to environmental conditions. Global Ecology and Biogeography, 21:224-235.

Lee S, Seo PJ, Lee HJ \& Park CM (2012) A NAC transcription factor NTL4 promotes reactive oxygen species production during drought induced leaf senescence in Arabidopsis. Plant Journal, 70:831-844.

Lim PO, Kim HJ \& Nam HG (2007) Leaf senescence. Annual Review of Plant Biology, 58:115-136.

Lopes A (2015) Fenologia foliar da floresta amazônica de terra firme por imagens digitais RGB. Dissertação de mestrado. Instituto Nacional de Pesquisas da Amazônia, Manaus. 38p.

Lorenzi H (2009) Árvores brasileiras: manual de identificação e cultivo de plantas arbóreas nativas do Brasil. $3^{\text {a }}$ ed. São Paulo, Nova Odessa, Plantarum. 384p.

Marenco RA \& Vieira G (2005) Specific leaf area and photosynthetic parameters of tree species in the forest understorey as a function of the microsite light environment in central Amazonia. Journal of Tropical Forest Science, 17:265278 .

Maruyama Y, Nakamura S, Marenco RA, Vieira G \& Sato A (2005) Photosynthetic traits of seedlings of several tree species in an Amazonian forest. Tropics, 14:211-219.

Matsuki S \& Koike T (2006) Comparison of leaf life span, photosynthesis and defensive traits across seven species of deciduous broad-leaf tree seedlings. Annals of Botany, 97:813817 .

Mendes KR \& Marenco RA (2010) Leaf traits and gas exchange in saplings of native tree species in the Central Amazon. Scientia Agricola, 67:624-632.

Morton DC, Nagol J, Carabajal CC, Rosette J, Palace M, Cook BD, Vermote EF, Harding DJ \& North PR (2014) Amazon forests maintain consistent canopy structure and greenness during the dry season. Nature, 506:221-224.

Munné-Bosch S \& Alegre L (2004) Die and let live: leaf senescence contributes to plant survival under drought stress. Functional Plant Biology, 31:203-216.

Nakamura S \& Izumi M (2018) Regulation of chlorophagy during photoinhibition and senescence: lessons from mitophagy. Plant and Cell Physiology, 59:1135-1143.

Oliveira MF \& Marenco RA (2019) Gas exchange, biomass allocation and water-use efficiency in response to elevated $\mathrm{CO}_{2}$ and drought in andiroba (Carapa surinamensis, Meliaceae). iForest-Biogeosciences and Forestry, 12:61-68.

Reich PB \& Flores Moreno H (2017) Peeking beneath the hood of the leaf economics spectrum. New Phytologist, 214: 13951397.

Reich PB, Uhl C, Walters MB, Prugh L \& Ellsworth DS (2004) Leaf demography and phenology in Amazonian rain forest: a census of 40000 leaves of 23 tree species. Ecological Monographs, 74: 3-23. 
Reich PR (1995) Phenology of tropical forests: patterns, causes, and consequences. Canadian Journal of Botany, 73:164-174.

Russo SE \& Kitajima K (2016) The ecophysiology of leaf lifespan in tropical forests: adaptive and plastic responses to environmental heterogeneity. In: Goldstein G \& Santiago LS (Eds.) Tropical Tree Physiology: Adaptations and Responses in a Changing Environment. Cham, Germany, Springer. p.357383 .

Schöngart J, Piedade MTF, Ludwigshausen S, Horna V \& Worbes M (2002) Phenology and stem-growth periodicity of tree species in Amazonian floodplain forests. Journal of Tropical Ecology, 18:581-597.
Shaver GR (1981) Mineral nutrition and leaf longevity in an evergreen shrub, Ledum palustre ssp. decumbens. Oecologia, 49:362-365.

Shipley B (2006) Net assimilation rate, specific leaf area and leaf mass ratio: which is most closely correlated with relative growth rate? A meta analysis. Functional Ecology, 20:565-574.

Tichá I, Èatský J, Hodáòová D, Pospišilivá J, Kaše M \& Šesták Z (1985) Gas exchange and dry matter accumulation during leaf development. In: Šesták Z (Ed.) Photosynthesis during leaf development. Dordrecht, Netherlands. p.157-216.

Vincent G (2006) Leaf life span plasticity in tropical seedlings grown under contrasting light regimes. Annual Botany, 97:245255 . 